\title{
Studies on the intraspecific competition in dung-breeding flies II. Some biological phenomena induced by overcrowding in immature stages of Musca hervei Villeneuve (Diptera: Muscidae)
}

\author{
Kazuhiro Amano* \\ Tohoku National Agricultural Experiment Station, Morioka, Iwate 020-01, Japan
}

(Received: January 11, 1984)

Key words: Diptera, Muscidae, Musca hervei, density, competition.

\begin{abstract}
Laboratory studies were done to assess the effects of larval density within cow dung on the growth and development of Musca hervei Villeneuve. Various numbers of eggs were reared with a fixed amount of reconstructed cow dung. In general, high larval densities beyond a certain level caused a large decrease in sizes of subsequent pupae and adults, despite the fact that the ratio of pupal length to width was almost constant for all sizes in both sexes. Very small puparia, however, were thin-walled and fragile. These stunted pupae had a tendency to emerge into small adults, having corresponding size in heads and wings with the pupal size, in a shorter period than normal ones. There seemed to be a positive relationship between the pupal size and the survival period of subsequent adult flies in both sexes.
\end{abstract}

\section{INTRODUCTION}

Musca hervei Villeneuve is a common pest of livestock in Japan, and cattle are its primary host. The larvae are coprophagous and develop mainly in fresh cow dung which are an essential source of food, moisture, and refuge.

In northern Japan, a herd of 40 to 100 cows is pastured usually in about 50 hectare of farm mainly in mountain area to breed or to bring up from May to October, and chemical application is rarely carried out. Consequently, more than $100 \mathrm{~kg}$ of dung is produced by them in a certain area everyday which is, of course, to be used by many kinds of coprophagous insects including $M$. hervei.

* 天野和䆖：農林水産省東北農業試験場（干020-01 岩手県盛岡市下厨川字赤平 4)
Under these conditions, the species having short life-cycle and big fecundity such as $M$. hervei or the horn fly, Haematobia irritans L., are expected to develop an enormous population in summer and autumn, some of which produce a high incidence of eye disorders and also cattle-clustering causing a decrease in the rate of gaining weight in cattle due to lack of feeding time.

Lately, some attention has been given to an examination of the field relationship and interactions between immature stages of coprophagous insects that share the same habitat with each other, e.g., Cotton (1978), Moon (1980) and Wasti et al. (1975). All of them found that the development of insects in dung tended to be suppressed under the condition of inter- and/or intraspecific high density. In practice, for the purpose of controlling the horn fly which is one of the most serious biting pests of 
cattle in America and the larvae develop only in fresh cattle dung, it has been tried to introduce some coprophagous beetles from overseas to increase the frequency and intensity of competition within the coprophagous fauna, and in turn make dung limiting for the horn fly (Macqueen and Beire, 1975; Roth et al., 1983). Field studies through seasons on $M$. hervei adults at Morioka in Iwate Pref. indicated that they were highly variable in size, suggesting that keen competition for food among the coprophagous species in cow dung might occur (Amano, unpublished).

In an earlier paper, I discussed intraspecific competition in the yellow dung fly, Scatophaga stercoraria L. in cow dung (Amano, 1983). The objective of the present study is to evaluate how and what phenomena are brought about by intraspecific competition of $M$. herve $i$ in cow dung, these phenomena being of interest in the study of population trends in this species.

\section{Materials and Methods}

Fresh cow dung and eggs of $M$. hervei used in this study were collected from the dairy farm in the Tohoku National Agricultural Experiment Station in Iwate Pref. Every $800 \mathrm{~g}$ of fresh cow dung was placed, and moulded into a rough patty shape, on $c a$. $3 \mathrm{~cm}$ of damp soil in containers $(45 \times 30 \mathrm{~cm}$, and $20 \mathrm{~cm}$ deep), separately. Various numbers of the eggs were transferred to each surface of these 22 cow dung pats and retained by covering them with a sheet of paper to prevent the medium from dehydrating in a rearing room under semi-outdoor conditions. They were allowed to pupate in the soil. The time of pupation were monitored by checking some extra containers. All the pupae of 10,085 individuals which were removed from the soil were maintained according to the purpose of the checks as follows.

Check 1: Influence of larval density on pupal size and emergence time

Since the eggs transferred to cow dung pats were very numerous, the numbers of emerging pupae were regarded as the index of density level in immature stages. Pupae were picked out, counted, and measured under a binocular micrometer. At densities lower than 78, all pupae were measured; at higher densities a minimum of 40 pupae were measured. Those pupae were then reared at $17.5^{\circ} \mathrm{C}$ with $16 \mathrm{~L}: 8 \mathrm{D}$ and allowed to emerge into adults, the time of which was checked more than three times a day.

\section{Check 2: Relationship between pupal size and emergence time}

Two hundred and thirty pupae, the length of which ranged $c a .4 .5-9.0 \mathrm{~mm}$, were subsampled and sorted into 13 groups according to pupal length, and then reared under the same conditions as mentioned in Check 1. The sex and emergence time were recorded for each adult that emerged from each group.

Check 3: Relationships among pupal size, subsequent adult size, and their survival period

Eighty pupae of various sizes were sampled, measured and reared, individually in a cylindrical tube $(60 \mathrm{ml})$ in the same chamber mentioned above. They were allowed to emerge into adults and left undisturbed with only distilled water until the adults had died. The emergence time, sex, head width, wing length and death time were recorded for each adult. In addition, the head width and wing length were measured for some additional emerging flies which were independent from these adults.

\section{Results}

1. Influence of larval density on pupal size, and emergence time

The size of pupae was largely influenced by the density in the larval stages. The dung with fairly high egg densities was entirely consumed, leaving only fibrous material, as against the dung with a small number of eggs which was only fibrous in places. Compared with pupae from low densities, many of these from high densities were small, light coloured and fragile. The frequency of these stunted pupae increased as the density increased. Table 1 represents the relationship between the number of emergent pupae and their mean size. Up to a density of 251 
Table 1 Relationship between the number of emergent pupae from $800 \mathrm{~g}$ cow dung and their mean size.

\begin{tabular}{|c|c|c|c|c|}
\hline \multirow{2}{*}{$\begin{array}{l}\text { No. of } \\
\text { pupae }\end{array}$} & \multicolumn{2}{|c|}{ Pupal length } & \multicolumn{2}{|c|}{ Pupal width } \\
\hline & $\bar{x}(\mathrm{~mm})$ & $\begin{array}{l}\text { CV } \\
(\%)\end{array}$ & $\bar{x}(\mathrm{~mm})$ & $\begin{array}{l}\text { CV } \\
(\%)\end{array}$ \\
\hline 19 & 7.29 & 5.64 & 3.12 & 3.58 \\
\hline 36 & 6.87 & 5.31 & 3.05 & 5.30 \\
\hline 46 & 6.53 & 5.31 & 2.87 & 3.33 \\
\hline 78 & 7.10 & 3.08 & 3.17 & 3.09 \\
\hline 157 & 7.00 & 3.86 & 3.09 & 3.56 \\
\hline 219 & 6.87 & 3.50 & 3.08 & 4.29 \\
\hline 240 & 7.18 & 4.62 & 3.17 & 3.20 \\
\hline 251 & 7.04 & 4.48 & 3.11 & 4.03 \\
\hline 335 & 6.67 & 2.92 & 2.90 & 3.50 \\
\hline 361 & 6.62 & 4.39 & 2.95 & 4.16 \\
\hline 486 & 6.30 & 4.19 & 2.81 & 5.46 \\
\hline 493 & 6.30 & 7.51 & 2.81 & 8.56 \\
\hline 589 & 5.82 & 5.98 & 2.60 & 6.29 \\
\hline 673 & 5.72 & 8.24 & 2.54 & 8.92 \\
\hline 678 & 5.76 & 7.21 & 2.53 & 7.50 \\
\hline 681 & 5.74 & 6.84 & 2.52 & 9.62 \\
\hline 718 & 5.99 & 5.79 & 2.66 & 7.46 \\
\hline 745 & 6.05 & 4.97 & 2.69 & 5.42 \\
\hline 752 & 5.45 & 8.10 & 2.42 & 7.91 \\
\hline 782 & 5.77 & 7.33 & 2.59 & 8.44 \\
\hline 831 & 5.49 & 14.03 & 2.54 & 18.13 \\
\hline 914 & 5.41 & 9.32 & 2.39 & 10.87 \\
\hline
\end{tabular}

emerging pupae, there was no relationship between pupal length and pupal density. The mean length of pupae in the range of 19-251 emerging pupae was $7.01 \mathrm{~mm}$. As the density of emerging pupae increased beyond this level, mean pupal length decreased, to be $5.41 \mathrm{~mm}$ at the highest pupal density. Coefficient of variation of them showed a tendency to increase as the pupal density increased. A similar pattern was observed in mean pupal width. Mean pupal length and width at the highest pupal density was $25.8 \%$ and $23.4 \%$ less than those at the lowest pupal density, respectively, which corresponds to a decrease of more than a half in volume.

Table 2 shows the mean time from the beginning of pupal rearing to adult emergence at each density level. The mean time for emergence tended to get earlier as the
Table 2 Relationship between the number of emergent pupae from $800 \mathrm{~g}$ cow dung and the mean time to adult emergence after placing in the incubator.

\begin{tabular}{|c|c|c|c|c|}
\hline \multirow{2}{*}{$\begin{array}{l}\text { No. of } \\
\text { pupae }\end{array}$} & \multicolumn{2}{|c|}{$\begin{array}{l}\text { Mean time for } \\
\text { emergence }\end{array}$} & \multicolumn{2}{|c|}{$\begin{array}{l}\text { Mean time for } \\
\text { emergence }\end{array}$} \\
\hline & $(9: \mathrm{hr})$ & $\mathrm{SD}$ & $(\hat{o}: \mathrm{hr})$ & $\mathrm{SD}$ \\
\hline 157 & 97.5 & 13.7 & 117.4 & 12.4 \\
\hline 219 & 98.3 & 11.3 & 115.1 & 13.4 \\
\hline 240 & 98.5 & 18.6 & 113.6 & 16.3 \\
\hline 251 & 80.7 & 19.1 & 105.3 & 12.2 \\
\hline 335 & 64.3 & 8.5 & 91.1 & 10.6 \\
\hline 361 & 71.7 & 10.3 & 92.3 & 11.3 \\
\hline 486 & 61.5 & 12.1 & 85.5 & 11.2 \\
\hline 493 & 66.1 & 11.8 & 86.5 & 11.0 \\
\hline 589 & 46.3 & 11.1 & 67.7 & 8.8 \\
\hline 673 & 51.1 & 11.9 & 70.3 & 11.4 \\
\hline 678 & 47.5 & 10.6 & 73.2 & 12.1 \\
\hline 681 & 40.8 & 11.3 & 63.3 & 9.2 \\
\hline 718 & 93.3 & 17.3 & 110.9 & 17.8 \\
\hline 745 & 90.4 & 14.9 & 110.8 & 15.8 \\
\hline 752 & 40.0 & 9.6 & 60.8 & 11.1 \\
\hline 782 & 43.3 & 13.3 & 67.7 & 14.4 \\
\hline 831 & 44.9 & 9.6 & 66.9 & 12.4 \\
\hline 914 & 41.2 & 11.0 & 62.7 & 12.5 \\
\hline
\end{tabular}

number of pupae increased beyond $c a .251$ in both sexes in addition to the significant positive relation between male and female development time $(p<0.01)$. Female adults emerged earlier than male at every density level. Adult emergence times, however, at the level of 718 and 745 emerging pupae were observed to get later than expected in both sexes. Detailed examination into Table 1 shows that the mean pupal sizes at these two levels were larger than ones at neighboring levels. These facts indicate that some unknown experimental errors seemed to act on the phenomena at those levels. However, they also indicate that there is a close relationship between the pupal size and emergence time.

\section{Relationship between pupal size and emergence time}

To clarify the relationship between the pupal size and emergence time, various sized pupae which had been grouped according 

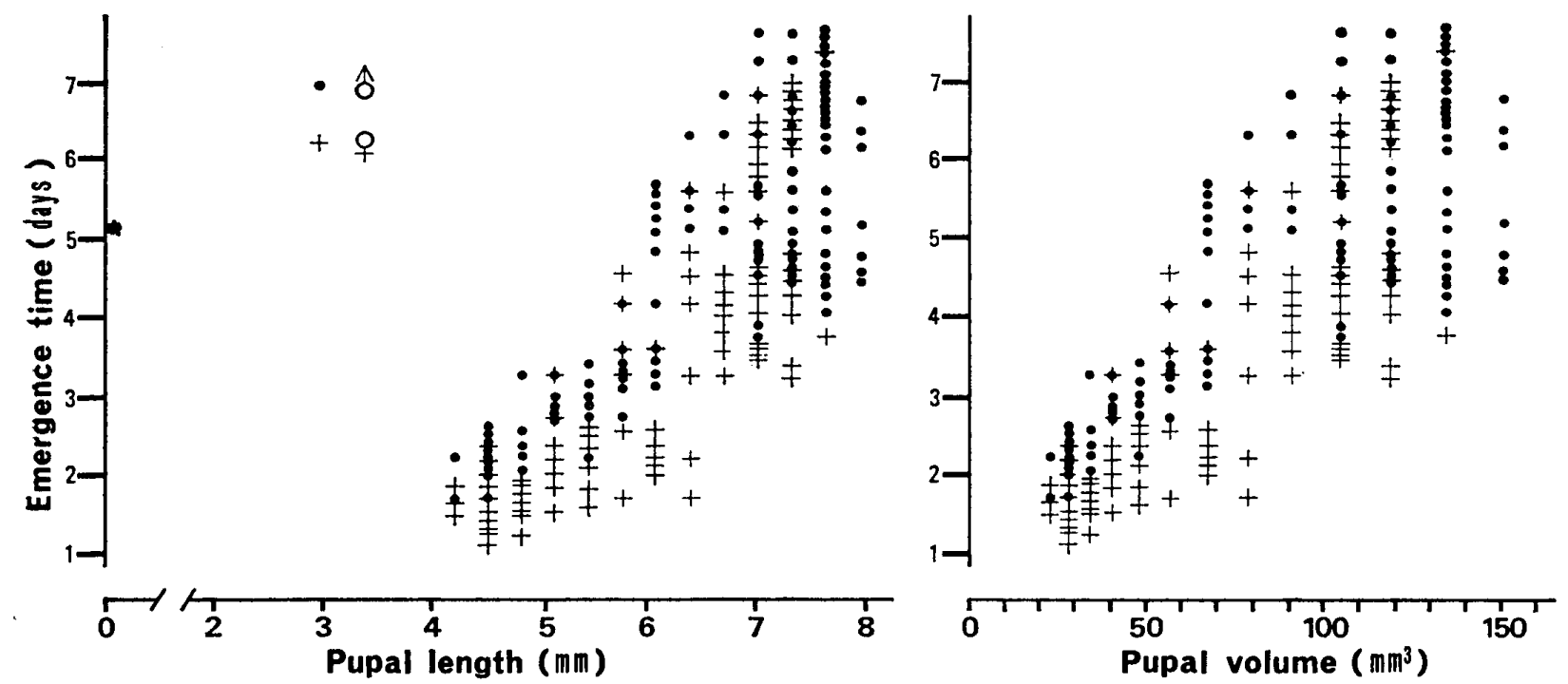

Fig. 1 Adult emergence time of male and female fly from various sized pupae.

Pupal body volume is shown by calculating the third power of the geometrical mean value of the length and width of a pupa. Emergence time is after placing pupae in the incubator.

to their sizes were reared to adults (Check $2)$. The results revealed that the smaller pupae emerged into adults in a shorter time and that female adults emerged earlier than male from the same sized pupae. Figure 1 shows the adult emergence time for the various sized pupae. Index of pupal body volume was calculated by raising the geometrical mean value of the length and width of pupae to third power. The value of pupal width was estimated using the equations in Fig. 3. Adult emergence time and pupal size were positively related. The relationship was linear when pupal size was estimated by volume and concaved when estimated by pupal length. This phenomenon indicates that the shortening of developmental period is more fitted in proportion to the decrease in pupal volume than in pupal length. Similar tendencies were observed in the relationship between the adult head width and emergence time obtained from the results of Check 3 (Fig. 2).

Consequently, correlation coefficients and partial correlation coefficients among density level, pupal volume and emergence time were presented in Table 3, during the density level more than 157 emerging pupae where both pupal volume and emergence time showed a tendency to decrease according to the intensity of density. The correlation coefficients showed a marked correlation

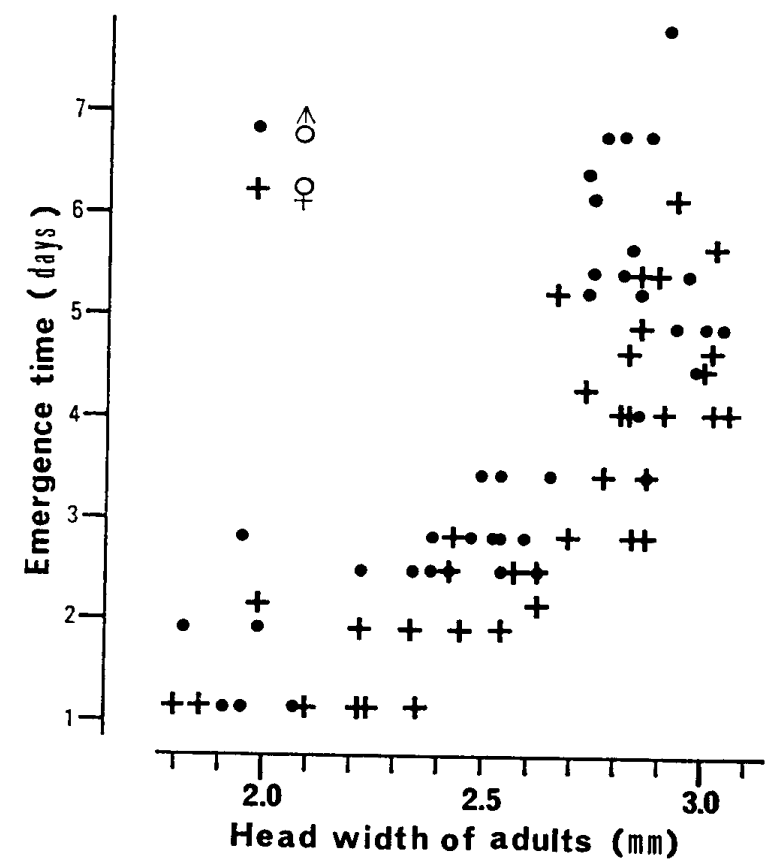

Fig. 2 Relationship between adult size and their adult emergence time.

Emergence time is after placing pupae in the incubator.

among these three factors, but the partial correlation coefficient between density level and emerging time were of no significance. This fact indicates that the emerging time of the same sized pupae would have no relationship to the intensity of density during larval stages, as against the pupal volume which would be directly relative to the density 
Table 3 Correlation coefficients and partial correlation coefficients among density level, pupal volume and emergence time.

\begin{tabular}{|c|c|c|c|}
\hline \multicolumn{2}{|r|}{ C.C. } & \multicolumn{2}{|c|}{ P.C.C. } \\
\hline$r \mathrm{~d} \mathbf{v}$ & $-0.952^{* * *}$ & $r \mathrm{dv} \cdot \mathrm{t}$ & $-0.923^{* * *}$ \\
\hline$r d t$ & $-0.701^{* *}$ & $r \mathrm{dt} \cdot \mathrm{v}$ & 0.492 \\
\hline$r_{\mathrm{vt}}$ & $0.817^{* * *}$ & $r \mathrm{vt} \cdot \mathrm{d}$ & $0.688^{* *}$ \\
\hline
\end{tabular}

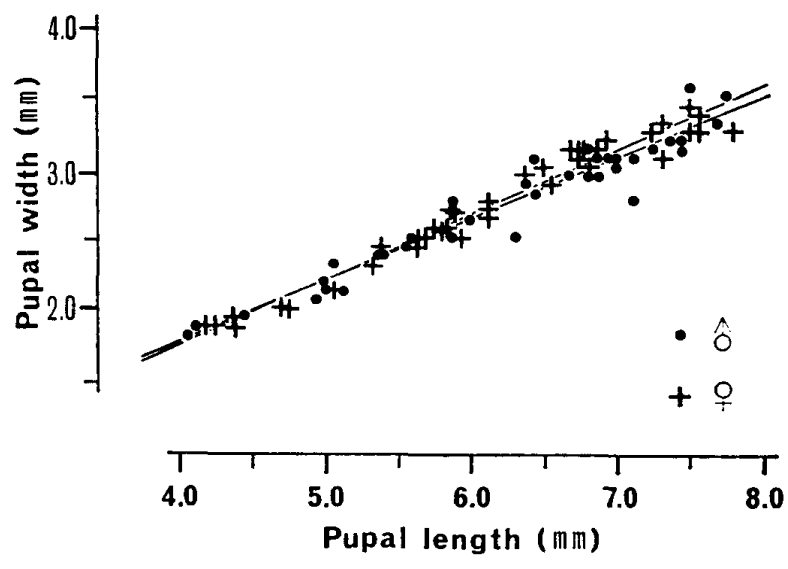

Fig. 3 Relationship between the length and width of lab-reared pupae.

Least-squares regression line is $Y=0.054+$ $0.429 X, \quad r=0.982$ for female, and $Y=$ $-0.007+0.456 X, r=0.956$ for male.

level.

3. Relationship betreen length and width of pupae of various sizes

A linear correlation between mean length and width of pupae was observed. Figure 3 shows the relationship between the length and width of the pupae of various sizes with respect to sex, which could emerge into adults. Pupal length and width were linearly related with each other in both sexes (female: $r=0.982$, male: $r=0.965$ ), and the equations for fitted lines of both sexes passed through the origin $(p>0.05)$. These facts imply that the ratio of pupal length to width was almost constant for all sizes of pupae. There was no significant difference in the equations between sexes, i.e. regression coefficient, and intercept of the regression lines $(p>0.05)$. This indicates that it is impossible to distinguish between the sexes of pupae by this ratio alone.

\section{Relationship between the sizes of pupae and subsequent adults}

It was observed that small pupae, resulting from high densities in the immature stages emerged into small adults. Figure 4 shows the head width of adults emerging from the various sized pupae which were reared individually as mentioned in Check 3. Geometrical mean value of pupal length and width was used as an index of pupal size. It shows a decrease in head width corresponding to a decrease in pupal size in both sexes. The analysis of variance for fitting a regression curve to the relation between pupal size and adult head width by orthogonal polynomials from a general recurrence formula shows that the first and second order terms are significant, and that higher order terms are neglected since their effects are small (Table 4). These facts indicate that as larval density increases, pupal size is more noticeably reduced than adult size.

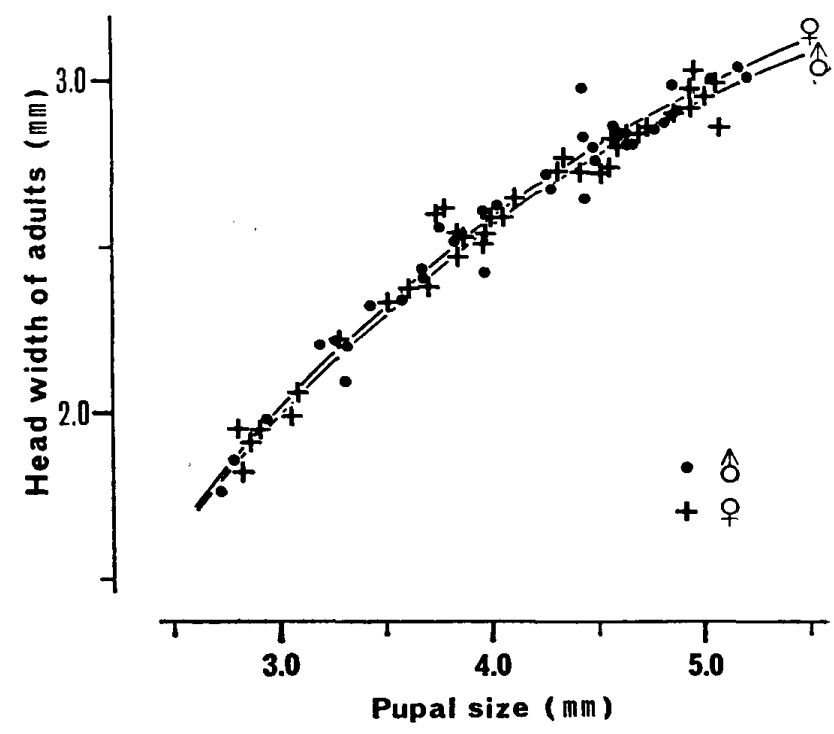

Fig. 4 Relationship between the sizes of pupae and subsequent adults.

Pupal size is shown by geometrical mean value of its length and width.

Regression curves were fit by orthogonal polynomials from a general recurrence formula, $\quad Y=-0.898+1.275 X-0.100 X^{2}$, $r^{2}=0.99$ for female, $Y=-0.803+1.219 X$ $-0.093 X^{2}, r^{2}=0.99$ for male. 
Table 4 Analysis of variance for fitting a regression curve to relation between pupal size and adult head width by orthogonal polynomials from a general recurrence formula for female (upper) and male (lower).

\begin{tabular}{lrrc}
\hline $\begin{array}{l}\text { Source of } \\
\text { variation }\end{array}$ & D.F. & \multicolumn{1}{c}{ M.S. } & F-ratio \\
\hline Mean & 1 & 1672.608 & $2183.716^{* * *}$ \\
Residual & 36 & 0.766 & \\
1st term & 1 & 26.102 & $620.795^{* * *}$ \\
Residual & 35 & 0.042 & \\
2nd term & 1 & 0.485 & $16.736^{* * *}$ \\
Residual & 34 & 0.029 & \\
3rd term & 1 & 0.004 & 0.142 \\
Residual & 33 & 0.030 & \\
4th term & 1 & 0.000 & 0.013 \\
Residual & 32 & 0.031 & \\
5th term & 1 & 0.004 & 0.133 \\
Residual & 31 & 0.032 & \\
Total & 37 & 45.951 & \\
\hline
\end{tabular}

\begin{tabular}{lrrc}
\hline $\begin{array}{l}\text { Source of } \\
\text { variation }\end{array}$ & D.F. & \multicolumn{1}{c}{ M.S. } & F-ratio \\
\hline Mean & 1 & 1696.729 & $2284.590^{* * *}$ \\
Residual & 38 & 0.743 & \\
1st term & 1 & 27.125 & $914.439^{* * *}$ \\
Residual & 37 & 0.030 & \\
2nd term & 1 & 0.451 & $25.134^{* * *}$ \\
Residual & 36 & 0.018 & \\
3rd term & 1 & 0.005 & 0.275 \\
Residual & 35 & 0.013 & \\
4th term & 1 & 0.000 & 0.000 \\
Residual & 34 & 0.019 & \\
5th term & 1 & 0.056 & 3.174 \\
Residual & 33 & 0.018 & \\
Total & 39 & 44.230 & \\
\hline
\end{tabular}

$* * * \quad p<0.001$

5. Relationship between head width of adult flies and their wing length

We can easily imagine that small flies would possess small wings. However, the wings have a special function for dispersal. Consequently, many different sized pupae from various larval densities were reared to adults individually, in order to elucidate the relationship between the body size of adults

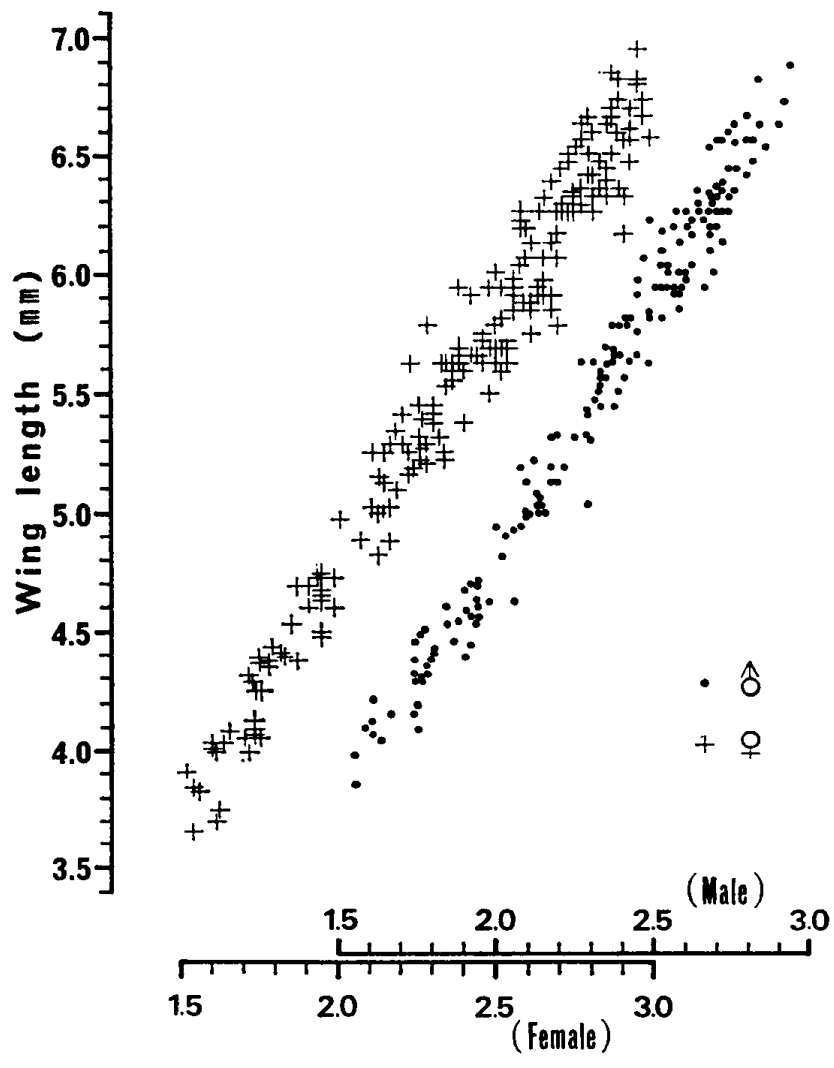

Head width of adults $(\mathrm{mm})$

Fig. 5 Relationship between the head width of adults and their wing length.

Least-squares regression lines are $Y=0.662$ $+2.050 X, r=0.98$ for female, and $Y=$ $0.569+2.113 X, r=0.99$ for male.

and wing length. Head width was measured on behalf of the body size for reason of accuracy. Figure 5 represents the relationships between the head width of adult flies and wing length in both sexes. A simple mechanism can account for the relaiton between them. Head width and wing length were linearly related ( $r>0.98$ in both sexes) with large flies having longer wings than small ones. This is supported by the following observation. The relative growth relation between them can be shown by an equation: $Y=b X^{a} \quad(Y$; wing length, $X$; head width, $a$ and $b$; coefficient). Values of $a$ were calculated to be 0.89 and 0.88 in male and female, respectively. These values of $a$ mean that these two characters almost vary homologously in accordance with fluctuations in the body size. Therefore, the density in the immature stages has no effect on the wing length-body size relationship. 


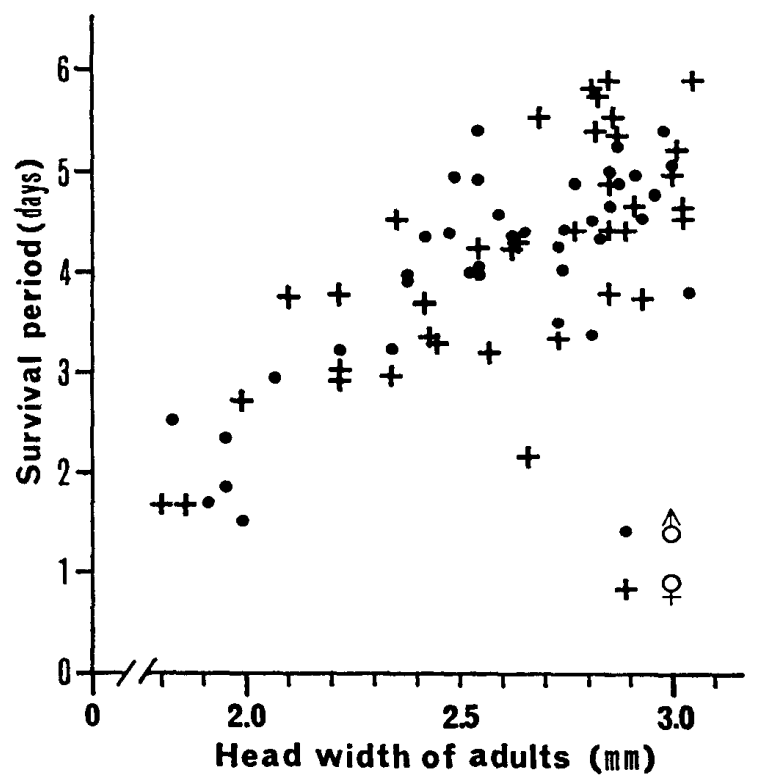

Fig. 6 Relationship between the head width of lab-reared adults and their survival period from emergence with only distilled water.

\section{Relationship between adult size and their survival period}

Decrease in the size of emergent adults brought about by high larval density had a drastic effect on their survival. The adult size and the survival period of the adults were observed to be positively correlated, and there was no significant difference between the sexes (Fig. 6). This suggests that the smaller sized adults would have a shorter life span in the field.

\section{Discussion}

Musca hervei Villeneuve is commonly found in pastures, especially in northern and central parts of Japan (Hasegawa, 1982), and regarded as a severe pest that would reduce milk production and weight gain of cattle in addition to being a vector of eye-worms, Thelazia spp. (Miyamoto et al., 1967). The present species is ordinarily observed in pastures to lay eggs on the suitable parts of dung pats in groups of females, mostly in summer and autumn. Once eggs are laid beyond a certain density level up to which a cow pat get their larval period completed normally, some interference for food or space among them will be brought about.
In general, the results of the experiments indicate that the smaller adult flies from overcrowding conditions in larval stages, with so much less vigour, emerged slightly earler in accordance with the intensity of larval competition. The same things are well-known on the intraspecific competition in the face fly, $M$. autumnalis DeGeer, which is one of the most important livestock pests in America, Canada, and Europe, and furthermore, is a similar species with the present one morphologically and biologically (Pickens and Miller, 1980). Moon (1980) studied larval competition in the face fly and reported that where competition was intense, so many stunted adults were produced, emergence time of which got earlier than normal sized ones, and that intensity of larval density was correlative with the mortality in immature stages, the reduction of subsequent adult size, the duration of the pre-reproductive period, and the reduction of fecundity of females, but not with the longevity of the surviving adults. Bornemissza (1970) has also reported that shortage of dung caused by some beetles reduced the number of emerging bushfly, $M$. vetustissima Walker, and made the small stunted flies of low or nil reproductive capacity.

Generally speaking, it seems that larval competition due to the increasing population levels will result in 1) restraint of the developmental rates in larval and pupal stages, 2) dispersal to another habitat, 3 ) reduction in size and weight of emergent adults, and 4) high mortality in immature stages (Amano, 1983). In the present species the mean time to adult emergence at higher larval densities more than 752 emerging pupae was $c a .50 \mathrm{~h}$ earlier than that at densities lower than 251, that is, no restraint of the developmental rate in immature stages was recognized under overcrowding conditions. Similar tendency was observed in the yellow dung fly which is coprophagous and shares a common habitat with $M$. hervei (Amano, 1983). On the other hand, in the house fly, $M$. domestica L., the stunted small adults due to overcrowding in larval stages emerge late compared with normal sized ones (Kitaoka, 1957). And also, food competition leads the house fly larvae to disperse from the medium even to the place where no food 
is expected (pers. obs.). This dispersal behavior was not observed in the present species even when the dung was consumed for the most part to be fibrous by them except when they were allowed to pupate in the soil. $M$. hervei breeds only in fresh dung which is a perfect ecological unit for it (Mohr, 1943) as against the house fly doing mainly in manur or compost which is free from quantity limit. From these facts it may be said that the larval dispersal ability of the present species seems to be feebler than that of the house fly larvae, and may also suggest that this ability would reflect the difference between their habitats.

These experiments were carrid out to gather basic information on interactions among the dung-breeding species which share a common larval medium with each other in nature. In this paper I did not deal with the mortality associated with the intensity of crowding. The relations arisen by the intensity of overcrowding in immature stages between the mortality of larvae and the rate of reduction in subsequent pupal or adult size will be published in the future.

\section{AGknowledgements}

I would like to express my appreciation to Professor M. Sasakawa, Kyoto Prefectural University, for the continuing encouragement and critical review of this manuscript. I also thank Chief entomologist Dr. T. Hasegawa and Dr. H. Hayakawa, both of this laboratory, for their helpful advices and criticisms and Dr. M. G. Hill, Entomology Division, DSIR, New Zealand, for reviewing an earlier draft of the manuscript.

\section{REFERENGES}

Amano, K. (1983): Studies on the intraspecific competition in dung-breeding flies. I. Effects of larval density on yellow dung fly, Scatophaga stercoraria L. (Diptera: Scatophagidae). Jap. J. Sanit. Zool., 34: 165-175.

Bornemissza, G. F. (1970): Insectary studies on the control of dung breeding flies by the activity of the dung beetle, Onthophagus gazella F. (Coleoptera: Scarabaeinae). J. Aust. ent. Soc., 9: 31-41.

Cotton, D. C. F. (1978): Laboratory evidence for intraspecific competition in the larvae of some Diptera living in cow-pats. Sci. Proc. $R$. Dublin Soc., A6: 155-164.
Hasegawa, T. (1982): Biological studies on flies associated with the pasturing cattle in northern Japan. I. Fauna and seasonal prevalence of the flies infesting pasturing cattle. Bull. Tohoku Natl. Agric. Exp. Stn., 66: 79-99 (in Japanese with English summary).

Kitaoka, S. (1957): Effects of population density and its phase change on the development of the house fly larvae. Jap. J. Sanit. Zool., 8: 192-198 (in Japanese with English summary).

Macqueen, A. and B. P. Beire (1975): Influence of other insects on production of horn $\mathrm{fly}$, Haematobia irritans (Diptera: Muscidae), from cattle dung in south-central British Columbia. Can. Entomol., 107: 1256-1264.

Miyamoto, K., H. Tanaka and R. Kano (1967) : Studies on intermediate hosts of bovine Thelazia III Surveys in Hokkaido and Kanto districts. Jap. J. Sanit. Zool., 18: 255-259 (in Japanese with English summary).

Mohr, C. O. (1943): Cattle droppings as ecological units. Ecol. Monogr., 13: 277-298.

Moon, R. D. (1980): Effects of larval competition on face fly. Environ. Entomol., 9: 325-330.

Pickens, L. G. and R. W. Miller (1980): Biology and control of the face fly, Musca autumnalis (Diptera: Muscidae). J. Med. Entomol., 17: 195-210.

Roth, J. P., G. T. Fincher and J. E. Summerlin (1983): Comparison and predation as mortality factors of the horn fly, Haematobia irritans (L.) (Diptera: Muscidae), in a central Texas pasture habitat. Environ. Entomol., 12: 106109.

Wasti, S. S., D. W. Hosmer and W. E. Barney (1975): Population density and larval competition in Diptera. I. Biological effects of intraspecific competition in three species of muscid flies. Z. Angew. Entomol., 79: 96-103.

\section{摘 要}

牛糞内に生息するハエ類の種内競合 に関する研究

II . ノイエバエの幼虫期における過密度が もたらす生熊的現象

一定量の牛糞塊 22 個にノイエバェ Musca hervei Villeneuve の卵を種々の密度に接種し, 飼育するこ とによって 10,084 個体の蛹を得た. それらの蛹を恒 温室 $\left(17.5^{\circ} \mathrm{C}, 16 \mathrm{~L}: 8 \mathrm{D}\right)$ で, 調查目的ごとに飼育お よび計測を行い，以下の知見を得た。

1. 牛粪 $800 \mathrm{~g}$ より産出される蛹数が 251 を超える と, 密度の増大にともなって蛹の平均長径および短径 が減少した(表1). また，成虫羽化までの平均日数は， 上記の密度水準以上では短縮される傾向があった. 雌 
雄間では睢のほうが短かかった（表2）。

2. さまざまな大きさの蛹について長径と短径との 関係をみると, 雌雄とも一定の直線関係が認められた （図 3). また，羽化時期については小型の蛹ほど早ま り，その短縮は蛹の長径よりも体積とのあいだに直線 関倸が見られた（図 1).

3. 蛹の大きさ（長径と短径の幾何平均）と羽化成虫 の頭幅とのあいだには雌雄とも有意な放物線関係を示
し，蛹の大きさのばらつきが成虫頭幅のそれより若干 大きい傾向を示した（図 4, 表 3). 乙かし，成虫頭幅 と翅長とのあいだには雌雄とも直線関係がみられた (図 5).

4. 成虫の大きさ (頭幅) とその生存期間との関係に ついては雌雄とも小型化するほど短期間となる。しか し, 雌雄間に有意差は認められなかった。 